\title{
LegioLit: Knappable material lithotheque in the Prehistory Laboratory at the University of León, Spain
}

\author{
Diego Herrero-Alonso ${ }^{1}$, M. Natividad Fuertes-Prieto ${ }^{2}$, \\ Esperanza Fernández-Martínez ${ }^{3}$, Fernando Gómez-Fernández ${ }^{4}$, \\ Eduardo Alonso-Herrero ${ }^{5}$, Ana $\mathrm{M}^{\mathrm{a}}$ Mateo-Pellitero ${ }^{6}$, Ana Neira-Campos ${ }^{2}$ \\ 1. Departamento de Prehistoria, Historia Antigua y Arqueología, Universidad de Salamanca, Spain. \\ Email: dherreroalonso@usal.es \\ 2. Área de Prehistoria, Universidad de León. Departamento de Historia, Facultad de Filosofía y Letras, Campus \\ de Vegazana s/n, 24071 León, Spain. Email: Fuertes-Prieto: n.fuertes@unileon.es; \\ Neira-Campos: ana.neira.campos@unileon.es \\ 3. Área de Paleontología, Universidad de León, Spain. Email: e.fernandez@unileon.es \\ 4. Área de Prospección e Investigación minera, Universidad de León, Spain. Email: f.gomez@unileon.es \\ 5. Área de Edafología y Química del Suelo, Universidad de León, Spain. Email: ealoh@unileon.es \\ 6. independent researcher. Email: ana_villa1112@hotmail.com
}

\begin{abstract}
:
This work introduces a comparative collection located in the Prehistory Laboratory at the University of León (Spain) specialised in knappable raw materials, mainly comprising radiolarite and black chert (micro-crypto crystalline quartz), from the western Cantabrian Mountains (north of Iberian Peninsula). A standardised protocol of sample collection and data organisation was developed, which includes the use of several methodologies. First, Geographical Information Systems (GIS) for referencing lithic sources. Second, direct observation of the sample for the macroscopic characterization, both de visu and stereomicroscope. Third, petrographic microscopy for a description of main petrological, and palaeontological features, complemented with the identification of the different minerals that make up the samples by X-ray diffraction (XRD). Forth, X-Ray Fluorescence (XRF), Inductively Coupled Plasma Optical Emission Spectrometry (ICP-OES) and Thermogravimetry - Differential Scanning Calorimetry (TG-DSC) for geochemical and thermal features of the samples. Finally, the results of these analyses were entered in a database. All this information is contributing towards the creation of a physical reference collection specialised in local Palaeozoic formations (mostly from Devonian to Carboniferous) that outcrop in the western Cantabrian Mountains, a region whose potential resource base was previously not very well known. This collection would allow to compare archaeological lithic remains from different sites inside and outside the Cantabrian Mountains.
\end{abstract}

Keywords: chert; radiolarite; database; lithotheque; lithic raw materials; Cantabrian Mountains; Iberian Peninsula

Published by the School of History, Classics and Archaeology, University of Edinburgh ISSN: 2055-0472. URL: http://journals.ed.ac.uk/lithicstudies/

Except where otherwise noted, this work is licensed under a CC BY 4.0 licence. 


\section{Introduction}

The lithotheque here presented (LegioLit) belongs to the Prehistory Laboratory, located in the Arts Faculty (Facultad de Filosofía y Letras, Vegazana Campus) at the University of León (Spain) (Figure 1). In this work we present the general outcome and some basic facts about its composition and the methodology applied. Therefore, this paper should be considered as a preliminary introduction of an ongoing project.

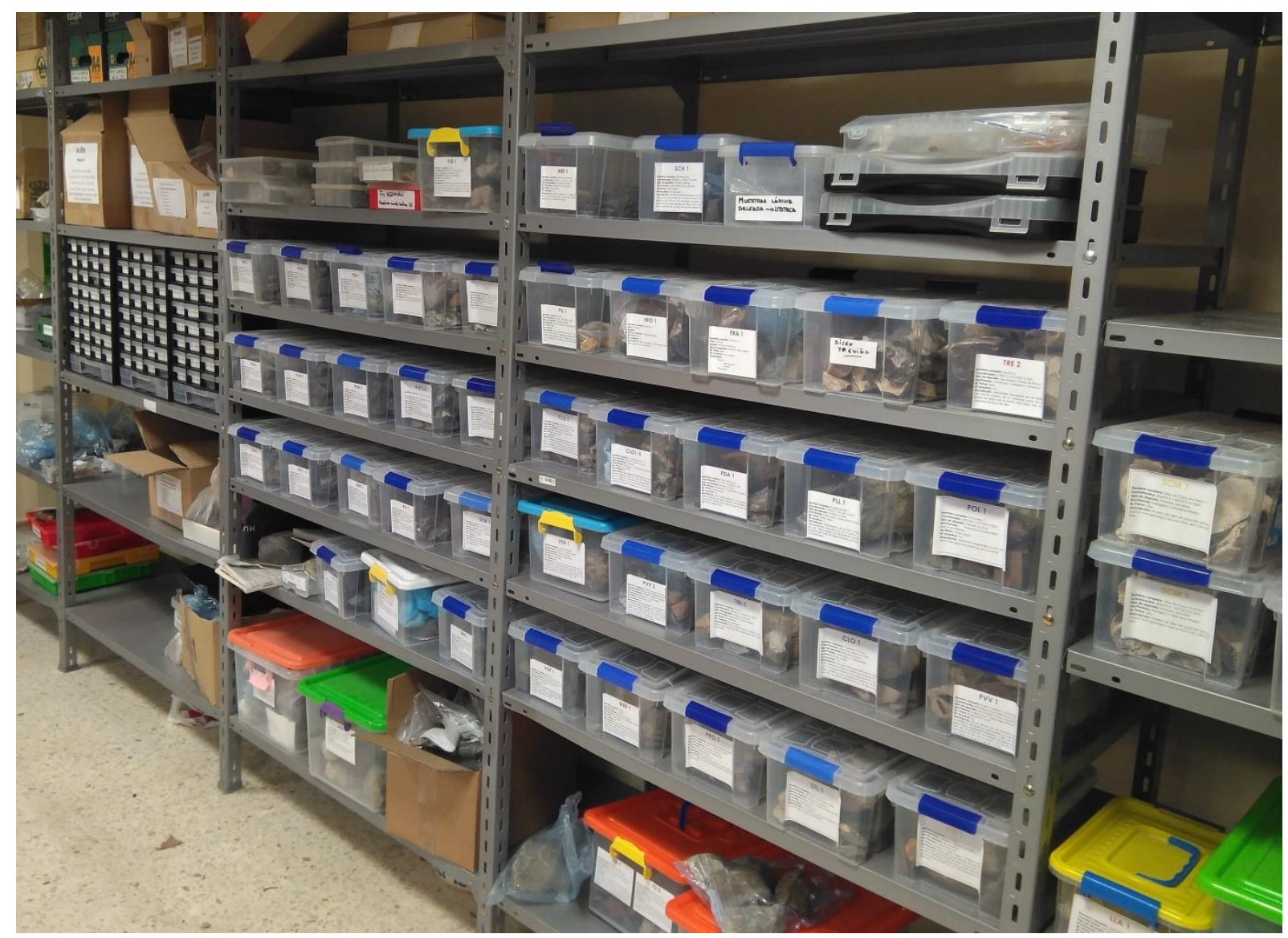

Figure 1. General view of the LegioLit in the Prehistory Laboratory at University of León.

This collection is specifically composed of knappable raw material, i.e. those suitable for the manufacture of stone tools by intentional fracturing. Most of these materials are flint or chert. Although these two names have been very used in archaeological bibliography, their usage is currently a controversial topic. In order to avoid this controversy, in this lithotheque we use the acronym MCCQ to refer to all the varieties of micro and crypto-crystalline quartz rock. On the other hand, "chert" is used to refer only to the varieties that outcrop in the Palaeozoic area of the Cantabrian Mountains (Cantabrian and Asturo-leonese geological regions), being this term very closely linked to the usage in the specific geological literature on this area. In addition, the term "radiolarite" is used to refer to the chert formed by an accumulation of radiolarians, which has a similar tradition in the literature.

The creation of this lithotheque started in the late 1980s and early 1990s, with the first collections of cherts from the Cantabrian Mountains, as part of the research projects being carried out at some Mesolithic sites near Riaño (northeast of León) (Bernaldo de Quirós \& Neira 1992). At that time, at least two main general types (apart from other minority varieties) of MCCQ raw material had been macroscopically identified in the archaeological remains: black chert and radiolarite. "Black chert" was also cited as local MCCQ in other archaeological sites of western Cantabrian Mountains in the northern slope. In fact, "black 
chert" (or "black flint") and radiolarite are considered common MCCQ raw materials (though of bad quality for knapping) in this geographical zone (centre-west of the Cantabrian Mountains) (Arias 1990). The scarcity of MCCQ formations in the western sector of the Cantabrian Mountains (corresponding to the Palaeozoic Cantabrian Zone) has been frequently pointed out (Arias 1990). This scarcity becomes especially evident when the MCCQ from this area is compared with the occurrence of some MCCQ varieties present in the Mesozoic eastern sector of the Cantabrian Range.

When the lithic assemblages from the archaeological sites, particularly from El Espertín Cave, began to be studied (Neira et al. 2004), the contents of the lithotheque increased and their study was the topic of a presentation at the $4^{\text {th }}$ Working Meeting on Procurement of Lithic Resources in Prehistory, held in Villamartín (Cadiz, Spain) in October 2007. The paper published in the proceedings of this meeting (Fuertes et al. 2010) proposed a textural classification of black cherts and radiolarites from the Cantabrian area, which has formed the basis of later studies. One of the main conclusions of this research is the discrimination of at least three different varieties of chert according to their lamination (or lack of it) and allochemical content, thus demonstrating a degree of variability in the group of local "black cherts". The characterisation of these different varieties was made possible by the collaboration of a multidisciplinary team including a palaeontologist (E. F.), a petrologist (F. G.) and a physical geologist (E. A.), all of them specialists in the geology of the Cantabrian Zone.

When the non-retouched lithic assemblage from another site near Riaño, La Uña Cave, began to be studied, a larger project to characterise all the local chert varieties outcropping in the Cantabrian Zone was proposed (Herrero 2014; 2018). In the course of this work, a total of 13 geological formations with Palaeozoic chert were identified. The comparative collection was enlarged with siliceous varieties from other geological areas, such as Asturo-leonese Zone, Duero Basin, Basque-Cantabrian Basin, Pyrenees, etc. (Figure 2). Samples belonging to this collection have been published in several papers such as those from Vegamián Formation (Herrero-Alonso et al. 2016), Escalada Formation (Fuertes-Prieto et al. 2016) and Mucientes locality (Fuertes-Prieto et al. 2014).

Concerning other similar projects in the Iberian Peninsula, three lithotheques have been created and published up to date. Two of them, LithicUB project, situated in the University of Barcelona (Mangado et al. 2010; Sánchez et al. 2014); and LitoCAT project, in the Milá y Fontanals Institution (CSIC) (Ortega et al. 2016; Terradas et al. 2012) mainly includes materials from north-east Spain (Catalonia). The third one, is LusoLIT project, at the University of Algarve (Faro) (Pereira et al. 2016) that mainly includes samples from the centre and south of Portugal. In this context, the LegioLit contributes to fill a gap in the northern of the Iberian Peninsula.

\section{The area of study: Geological context}

The lithotheque described in this paper gather material from the western part of the geographic region known as Cantabrian Mountains, which reach from Pyrenees to the west coast of the norther Iberian Peninsula. From a geological point of view, this region includes several geological zones both Palaeozoic and Mesozoic in age and it is bounded to the south by several Cainozoic (Tertiary) basins.

LegioLit is mainly focused on material from the Cantabrian Zone, one of the geological regions of the Iberian Massif (Figure 2). It is characterised by sedimentary rocks originating to Cambrian up to the Permian, but mostly corresponding to the Carboniferous and Devonian. In this geological context chert has been identified in a total of ten stratigraphic formations that are developed in Devonian and Carboniferous limestone. In addition, two varieties of 
radiolarite with claystone host rock and some chert that outcrops in the Pendueles flysch (Herrero 2016) are also included in the collection.

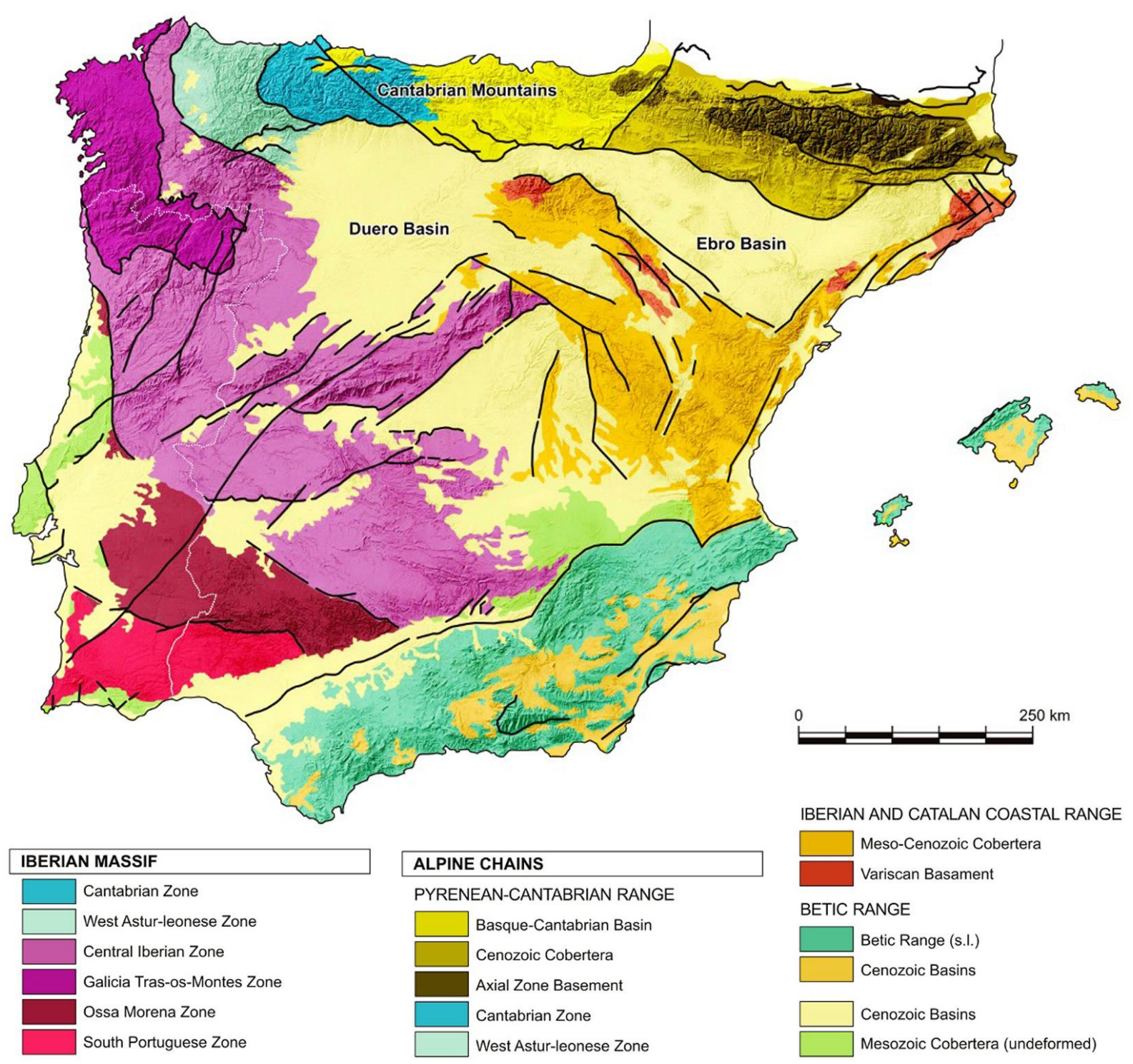

Figure 2: Geological map of Iberian Peninsula. Modified after Vera et al. (2004) and PePeEfe (2018).

\section{Objectives}

The main aim of LegioLit is to fill an existing void in the knowledge of the centralwestern sector of the Cantabrian Mountains as potential base for knappable raw materials. Before the creation of this collection, the chert outcropping in this area had not been studied from an archaeological point of view, and it was normally assigned to a heterogeneous group under the vague name of "black chert". Thus, the final goal of this collection is to provide a database that allows comparison among lithic remains from different archaeological sites. This comparison being the first step to determine the origin of the knappable material and further developing of other studies in prehistoric societies, such as procurement methods and mobility patterns.

This project is based on five steps:

-1. To identify all the local MCCQ varieties that outcrop in the Cantabrian Zone and to define the lithological potential of usable raw materials (almost exclusively chert, but also other rocks, such as quartzite, quartz, claystone, siltstone, etc.) 
- 2. To characterise all the varieties according to the same analytical protocol based on the textural description (both macroscopic and microscopic), identification of mineral phases, elementary composition, and thermal behaviour.

-3. To provide researchers with a reference collection allowing the comparison of the different varieties found in both geological and archaeological contexts.

-4. To complete the general distribution map of MCCQ in the Cantabrian Mountains, where research in other zones, such as the Basque-Cantabrian Basin, enjoys a long tradition (Tarriño, 2006; Tarriño et al. 2015).

-5. To design databases to include all the information obtained.

\section{Methods}

\subsection{Collection of samples}

The creation of a lithotheque implies several stages. The first of them is to gather geological and archaeological data of this region. For this purpose, we consulted several specialists and revised the specific literature, which was brought together in a bibliographic database.

With these data, 90 outcrops have been sampled in a long process of fieldwork that is still in progress. The number of samples collected from each outcrop varies mainly depending on the variability of the external features of the MCCQ. Samples of each outcrop have been stored in a box labelled with the basic information (georeference, type of outcrop -primary or secondary-, geological period of the formations containing primary MCCQ, type of raw material, etc.) (Figure 3). For each outcrop, a descriptive record that included its location, graphic documentation and photographs, among other information was created. Each of these records was added to the lithotheque database ("Outcrop" form).

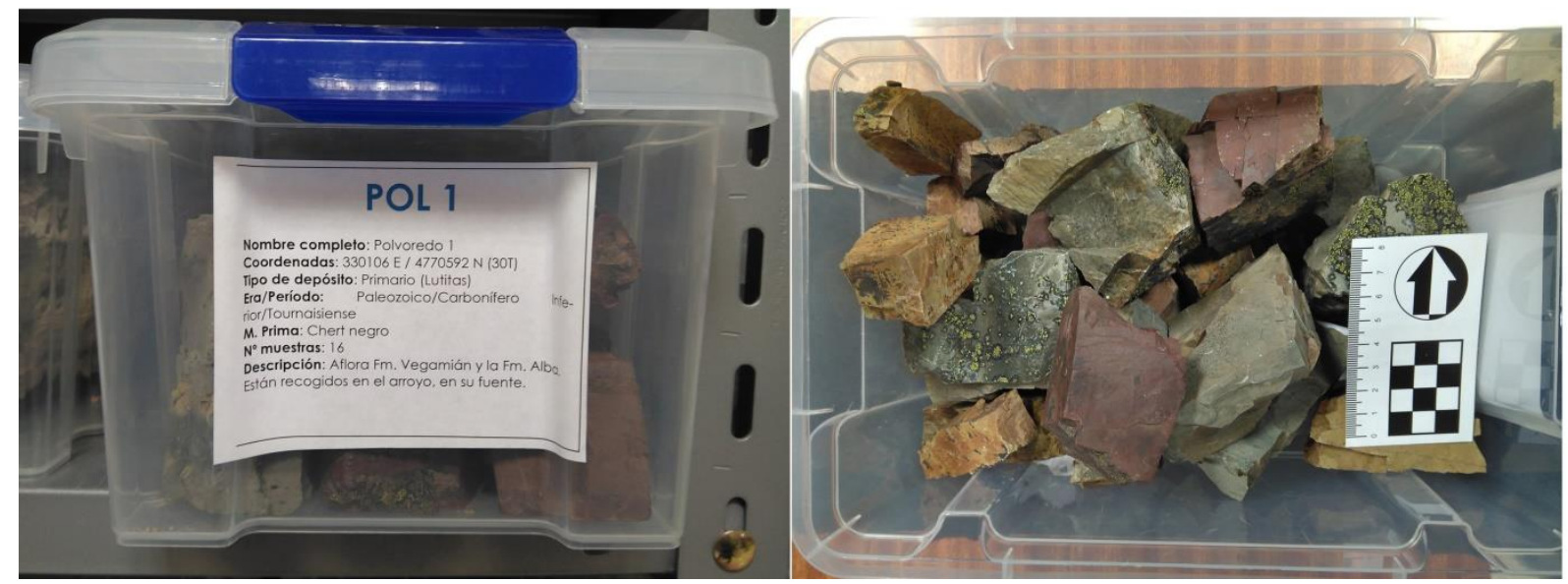

Figure 3: Samples from one of the studied outcrops, stored in their box and showing the high variability of the external features of the samples from a single outcrop.

\subsection{Macroscopic analysis}

A highly variable number (between about 10-50) of MCCQ were obtained at each of the outcrops. They have all been described from a macroscopic point of view, including two complementary techniques: observation de visu and with a stereoscopic microscope.

In the first case, the descriptions include the colour, trying to collect all the variety of tonalities, both in the cortical zone (considering also subcortical area) and internal core (Munsell 2013), the type of cortex (both colour and general texture), the lustre (although by definition quartz is glassy, some differences can be appreciated, like matt and waxy), 
transparency (consisting of three groups: transparent, translucent and opaque), and roughness (divided into soft, smooth and rough).

In the second case, the use of the stereoscopic microscope $(0,8-80 x)$ allows textural analysis to be added, including inclusions normally larger than $100 \mu \mathrm{m}$. Significant differences can be observed in the texture of the matrix they are classified into four groups: homogeneous (no changes in colour or morphology in the matrix, which is seen to be a similar mass from any angle), lens (this is a variety with a heterogeneous matrix, characterised by changes in colour with no particular pattern and therefore which changes colour depending the angle of observation), parallel lamination (the matrix changes colour in parallel or sub-parallel layers with different colours and tones) and lenticular laminations (the matrix has a certain resemblance to "flaser" lamination, characterised by quite large spindleshaped lenses that are never parallel to one another).

An important feature is the occurrence of special components in the matrix. In the studied samples, the presence of detrital quartz, relict carbonates, pyrite, authigenic dolomite and calcite, bioclasts and organic matter have been identified and used for inferring the probable geological provenance of every sample.

The observation under a petrographic microscope also allows the study of two more features. One of them is the macroporosity (when it is possible) even though the morphology and distribution of the pores cannot be always determined. The other one is the occurrence of natural fracture planes, which is relevant information for the evaluation of the quality of the MCCQ for knapping. Apart of the archaeological information, these two features can provide information on the formation and post-depositional processes that the materials have suffered and thus, they may contribute to the knowledge on the precise geological provenance of the samples.

\subsection{Textural analysis}

Out of all the samples studied macroscopically, a smaller sample (2-8, depending on the variability of the outcrop) was chosen for the full analytical protocol, which begins with a textural analysis of thin sections. This analysis focuses on orthochemical, allochemical and authigenic elements and alterations. This form is based on the proposal presented by Tarriño (2006), a slight modification of the Folk's proposal (1974).

The orthochemical components are chemical precipitates that hold together the elements in the matrix without transporting or adding other elements (Folk 1974: 1). Within this category, the cementation of the MCCQ is studied to determine the form taken by the quartz, and "mosaic", "fibrous" and both of them at the same time aggregates may be identified. The former of these is divided into three groups depending on the grain size: cryptoquartz $(<2$ $\mu \mathrm{m})$, microquartz $(2-20 \mu \mathrm{m})$ and megaquartz $(>20 \mu \mathrm{m})$. The fibrous varieties are divided into calcedonite, quartzine, lutecite and other complex forms.

The allochemical components are the clastic elements that form the structure of the silicified sedimentary rock and generally come from the interior of the same sedimentary basin. In our case, the following elements have been discriminated: intraclasts, peloids, pellets, ooids, aggregates, cortoids, organic material and bioclasts. Another group of components that have been studied are the relict minerals, which became trapped in the rock when it was formed. The most common minerals are carbonates, which have been divided into micrite $(<4 \mu \mathrm{m})$ and sparite $(>4 \mu \mathrm{m})$ (Folk 1974: 156) and terrigenous minerals (especially detritic quartz and other accessory minerals, like zircon and tourmaline). Some others that appear with certain frequency are oxides, sulphates and clays.

Authigenic or newly-formed minerals are grouped into another important category of elements to be differentiated. These are formed during the diagenesis or later. The most 
common minerals in this group are quartz, dolomite, calcite, pyrite, gypsum, glauconite and apatite. However, others appear less frequently, such as chalcopyrite and several types of feldspar.

Another aspect of the petrographic description focuses on the alterations that the rock has suffered, divided into thermal fissures, dissolution of some minerals, oxidation (hematite) and opalisation. The porosity aspect is also studied and, if porosity exists, the type; determining whether it is controlled by the grains, crystals or other structures.

\subsection{Mineralogical, geochemical and thermal analysis}

The identification of mineralogical phases is carried out with X-ray diffraction of polycrystalline powder. The main goal is to determine which minerals are present in the sample, both to confirm those described in previous stages of analysis and to identify new ones that are not observable by microscope.

The elementary composition of the samples has been studied with two techniques that can be complementary. The first of these is X-ray fluorescence, to determine the composition of minority elements in the form of oxide. Secondly, Inductively Coupled Plasma Optical Emission Spectrometry (ICP-OES) has been used to quantify in ppm the trace elements in the sample. The choice of techniques depends on the ultimate goal of the analysis because, for example, silicon cannot be quantified with ICP-OES, as the analytical process included digestion with hydrofluoric acid (HF).

The thermal behaviour of the samples has been studied with Thermogravimetry and Differential Scanning Calorimetry (TG-DSC). This allows quantifying the composition in volatile elements, such as organic matter and water, silanol, and both water and silanol, that it is not possible with other techniques.

\section{Organisation of the lithotheque}

All the data obtained has been organised in a structured schema, from more general to more specific characteristics (Figure 4).

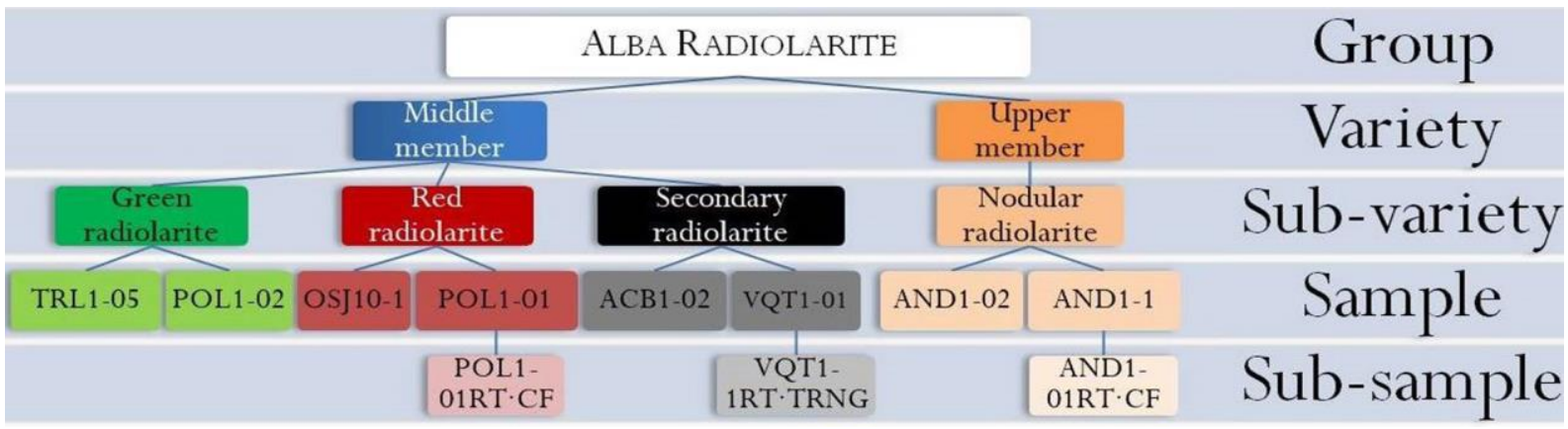

Figure 4: Example of the hierarchical organisation of the lithotheque.

\subsection{Raw material}

This feature refers to the most general classification of the raw material type (Figure 4). Even though this lithotheque is oriented to chert and radiolarite, we have gathered more raw materials such as quartzite, quartz, limestone, and lutite and sideritic nodules, all of them used by prehistoric groups in the Cantabrian Mountains area.

\subsection{Groups}

The group is the category associated with the geological formation or a particular lithology in a certain geological context. It is a very useful category from the archaeological 
point of view as it allows comparison between raw materials with similar characteristics, because in most cases it is not possible to be more specific from a macroscopic point of view.

Examples of "groups" in this lithotheque from the Cantabrian Mountains area is the "Alba radiolarites group", formed by all varieties from the Alba formation. Other groups defined in other zones of the north of Iberian Peninsula (Basque Country) are the "Treviño group" which includes all MCCQ types of lacustrine origin in the Araico-Cucho Mountains (Tarriño et al. 2014); or the "Flysch group", which gathers varieties like Kurtzia Flysch, Bidache, Mouguerre, etc. (Tarriño et al. 2015).

\subsection{Varieties}

Sometimes, a group of samples only includes a variety, such as it happens in the group called Piloña flint (Tarriño et al. 2013). But, in other cases, a single group can be divided into different varieties due to the occurrence of different features. For example, in "Alba radiolarites group", there are two varieties (Figure 4). The first variety corresponds to material coming from outcrops located in the upper member of the Alba Formation, and it is characterized for the occurrence of radiolarians and crinoids and the absence of a laminated matrix. The second variety includes samples coming from some outcrops located in the middle member (or Lavandera member) of the Alba Formation and is characterized by the occurrence of both radiolarians and laminated matrix.

In a few cases, some differences in a single variety, for example concerning the colour, have been observed. In these cases, and because the main characteristics are the same, we do not consider this difference to be another variety, but just a sub-variety. In the example of the Lavandera radiolarite variety, there are three different colours depending on the degree of alteration by leaching. These are sub-varieties because all the samples are featured by the occurrence of radiolarians and a laminated matrix.

\subsection{Samples}

The sample is the basic unit of study, which is characterised by observation with a stereomicroscope. This analysis allows the sample to be classified into one of the varieties. Each sample is identified by a reference number consisting of the acronym of the outcrop plus a serial number (Figure 5).

The samples that are selected for further analysis, such as X-Ray diffraction or thin sections, are called sub samples (Figure 4). These have a more specific reference number consisting of the acronym of the outcrop, plus a serial number, plus the acronym of the raw material and the age. In the case of a secondary position survey, the age cannot be defined and is replaced by a reference to its source.

\section{Databases}

All the data are collated in databases that allow them to be related and accessed intuitively. At the moment, three different types of records have been created, although they all share similar fields so that they can be related and consulted easily.

The first of these records is an Access-type database, which contains the information from all the studies, carried out on the minimum unit of analysis, which is the sample. Three basic forms have been created for the entry of this information:

i) "Sample" form. It contains the reference to the outcrop the sample comes from and the macroscopic description as explained above. It includes access to the form with the photographic record. Each sample pertains to a particular variety within a group (Figure 4) and a raw material category (chert, radiolarite, flint, quartzite, quartz, etc.). 
ii) "Microscopic analysis" form. It contains information from the textural analysis, including an image of the thin section. It also includes access to the form with the photographic record. When available, files with some results on mineralogical, geochemical and thermal analyses analysis are inserted using a hyperlink.

iii) "Outcrop" form. It contains information about the sample collection. Again, it includes access to the form with the photographic record.

A second database designed for the lithotheque project is a geodatabase, with the location of all the geological formations containing chert and radiolarite, and the outcrops associated with each formation.

Lastly, a similar type of file has been created, a .kml type, which can be opened easily using Google Earth, an open-access and widely used programme (Figures 6, $7 \& 8$ ). This type of file is very small, so it is easy to send and distribute, as well as being very intuitive. Each outcrop, ordered chronologically and according to the formations, shows a drop-down menu with some of the data included in the "outcrop" form (Figure 8). Additionally, it can easily be changed into a points shapefile for a GIS project, and added to a project in which the geological formations are already located in polygons layers.
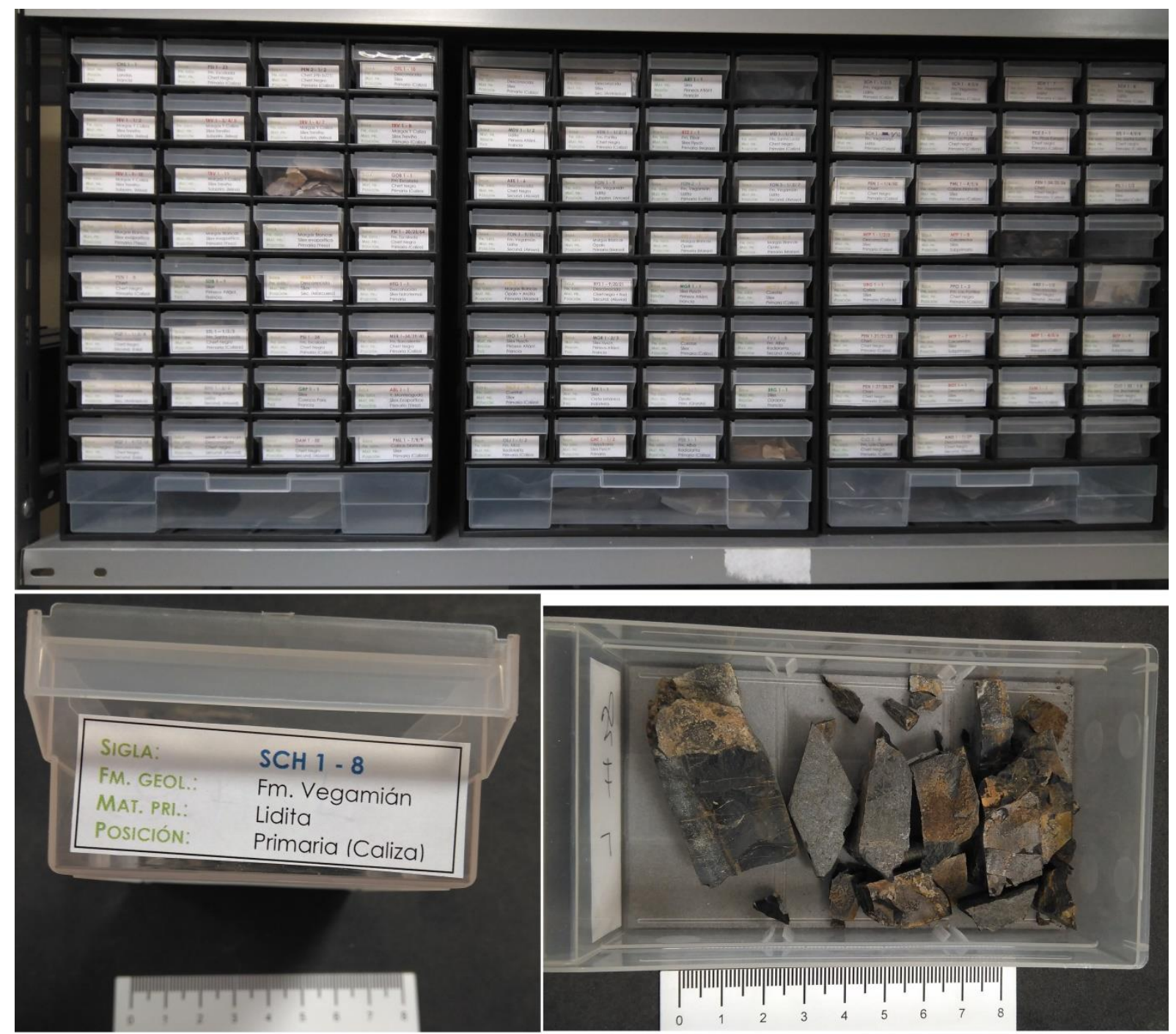

Figure 5: Pictures showing the organisation of the sample boxes (above), a detail of the labels of the sample boxes (below, left) and the inside of a sample box containing several samples (below, right). 


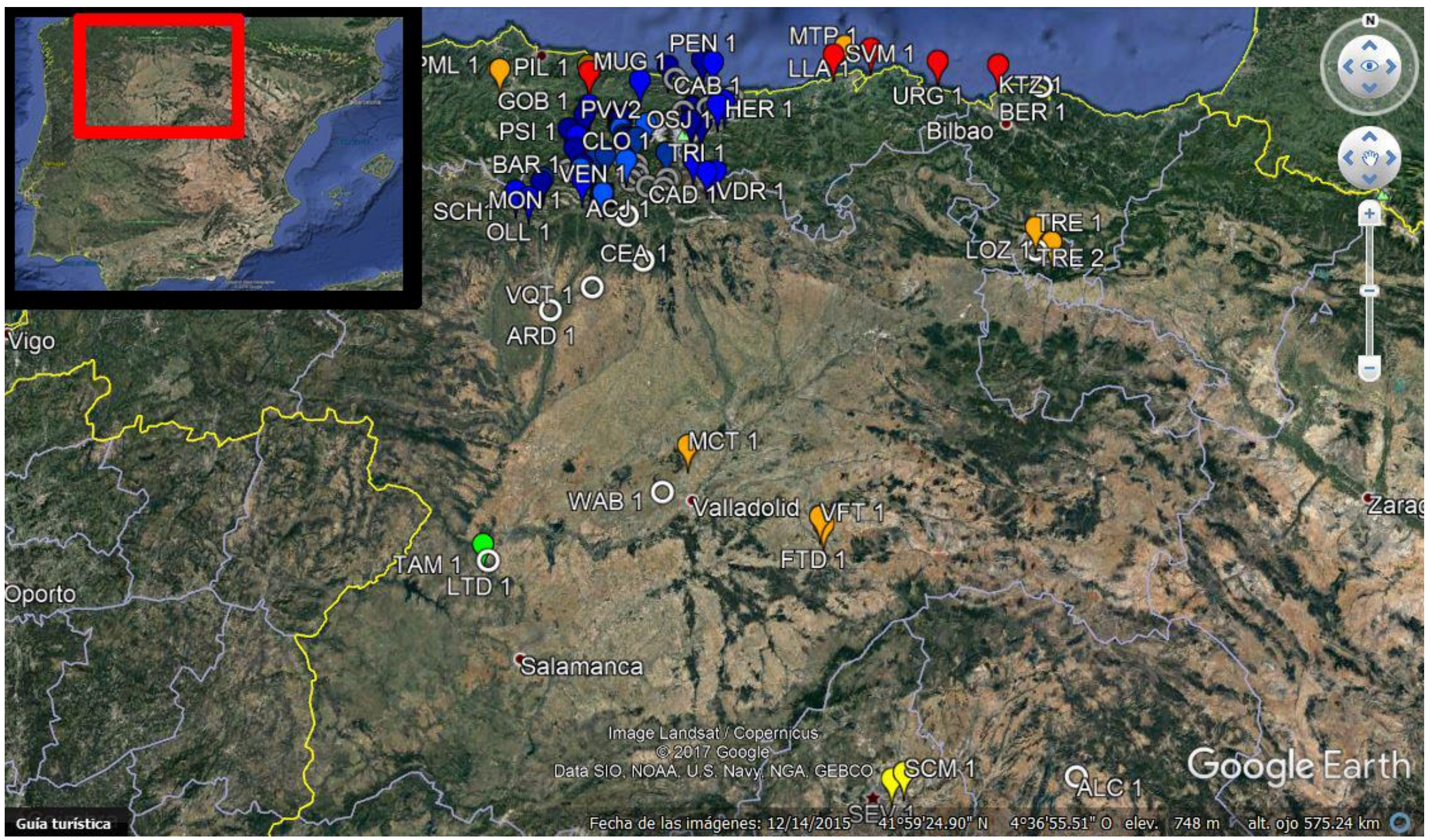

Figure 6: Map with the different outcrops included in the LegioLit at the University of León (Source: Google Earth). 


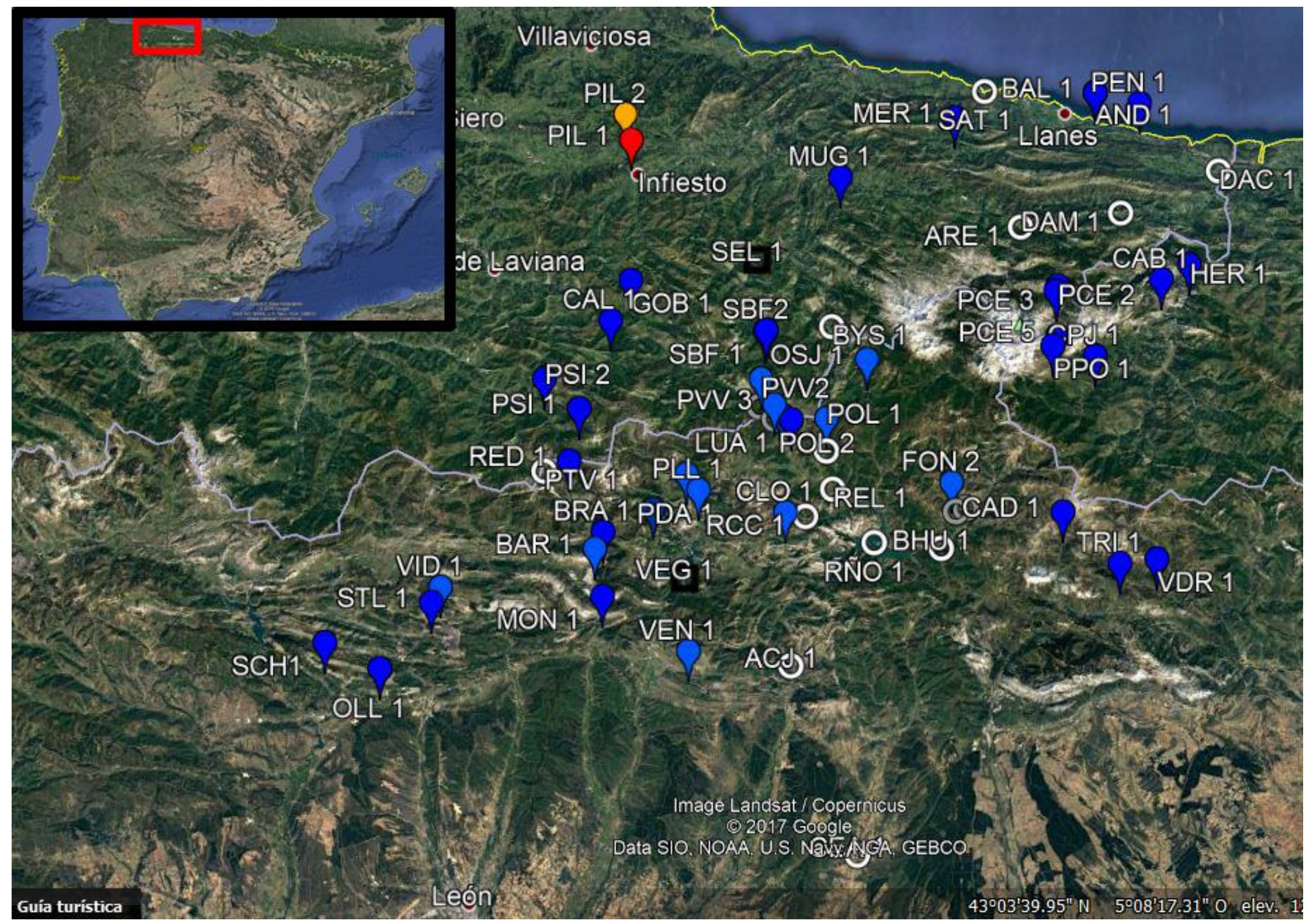

Figure 7: Map with the different outcrops in the target area (Source: Google Earth). 


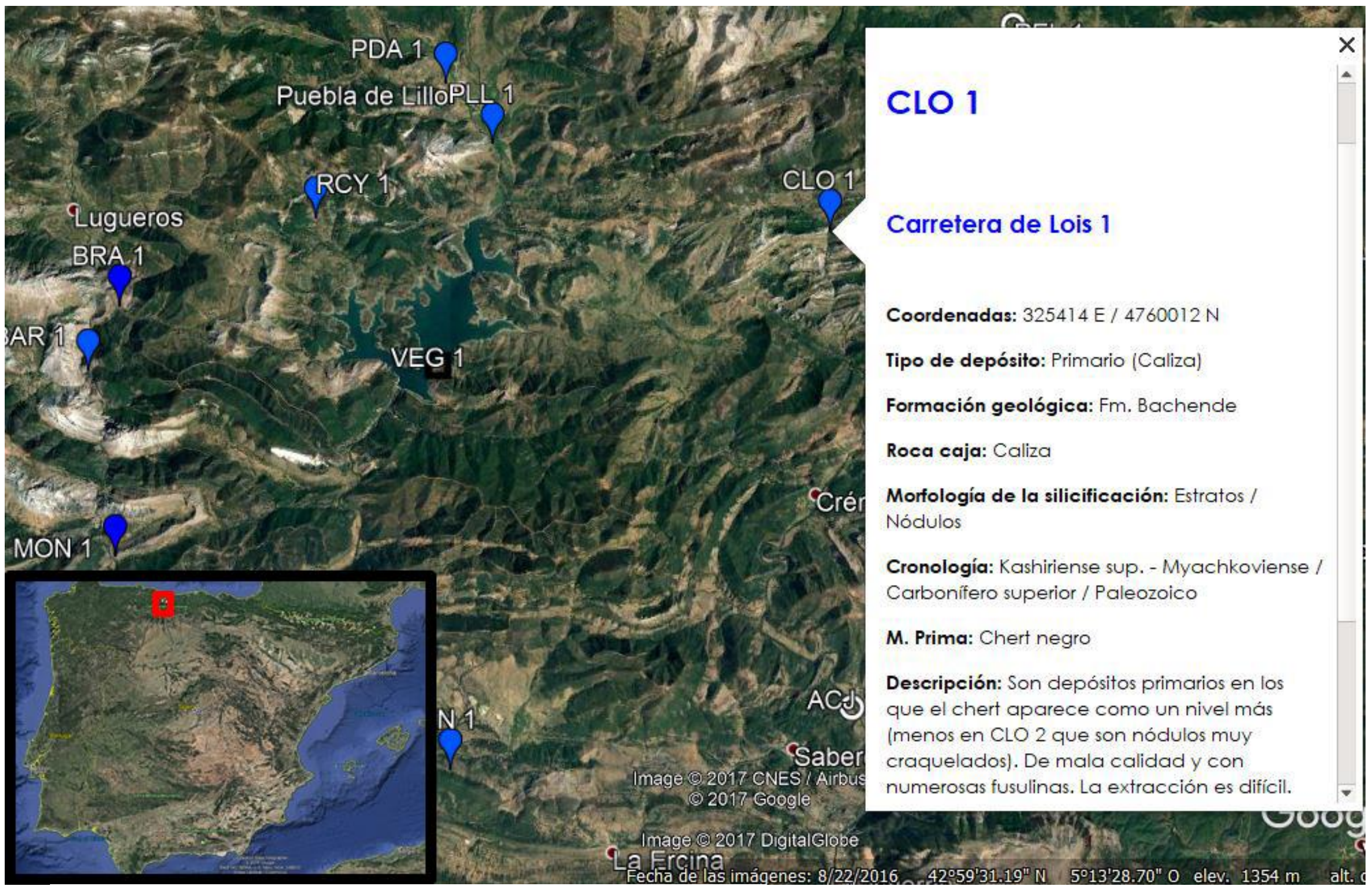

Figure 8: Example of the drop-down information menu that has been developed for each outcrop (Source: Google Earth). 


\section{Final remarks}

The lithotheque in the Prehistory Laboratory at the University of León (LegioLit) is currently under elaboration and, thus, we have presented here the overall schema and the general principles and methodology that sustain this project. The collection is focused on the chert and radiolarite in the western sector of the Cantabrian Mountains (Palaeozoic Cantabrian Zone), in the north of Spain, a region that is less well known in this field of study (the potential knappable raw materials available) than other areas. A recent review of this subject can be found in Tarriño et al. 2016.

In this paper, we describe the methodology applied for the organization of the collection and the analyses required for the description and definition of the raw materials considered. They include the analysis of the textural, mineralogical, geochemical and thermal attributes. The diversity of the raw materials is seriously considered so as to better define the different levels of organization, from "raw material" to "sample". The collection is complemented with MCCQ types from other areas, especially from the northern half of the Iberian Peninsula and the south of France.

One of the achievements of this project is the differentiation of the a priori homogenous macroscopic "black chert" raw material into several groups, all of them associated with geological formations from the Cantabrian Mountains. The use of the methodology explained in this work has permitted to identify specific features of each group, as is the case of Vegamián and Escalada cherts (Fuertes-Prieto et al. 2016; Herrero-Alonso et al. 2016). Moreover, the thirteen formations with black chert and radiolarite, as well as other MCCQ groups, have been defined in the PhD of one of us (D.H.) (Herrero-Alonso 2018). All this information has been used to identify the provenance of the raw materials (local versus foreign) knapped in archaeological sites such as El Espertín and La Uña caves (Fuertes et al. 2010; Herrero 2014; 2018; Neira et al. 2016).

Although the project started in the 1990s, the fieldwork and research has expanded in the last ten years and is still in progress. Two lines of research are currently being followed for the lithotheque. First, to complete and unify all the data in a single database and improve the internal relations between tables and forms. Second, to publish the data on-line, as done by other projects of this kind, such as LithicUB (LithicUB 2012; Sánchez et al. 2014).

\section{Acknowledgements}

We acknowledge all researchers that have participated indirectly in the formation of this lithotheque, both for the raw materials from some areas and for their knowledge about different topics that were necessary to initiate this project. We specially thank Dr. Andoni Tarriño for facilitating the samples from Vasco-Cantabrian Basin, Dr. Rodrigo Castaño de Luis for his collaboration with map edition and the anonymous reviewers, whose comments have contributed to improve this paper.

\section{References}

Arias, P. 1990, Utilisation différentielle des variétés de silex au chalcolithique dans les Asturies orientales (Espagne). In: Le silex de sa genèse à l'outil. Actes du Ve Colloque International sur le silex (Bordeaux, 1987) (Séronie-Vivien, M.R. \& Lenoir M., Eds.), Cahiers du Quaternaire 17, Vol. 2, Centre national de la recherche scientifique (CNRS), Paris: p. 449-452. (in French) ("Differential use of chalcolithic flint varieties in eastern Asturias (Spain)") 
Bernaldo de Quirós, F. \& Neira Campos, A., 1992, Mountain occupation sites in the Cantabrian Range (Spain). Preistoria Alpina, 28: 49-58

Folk, R.L., 1974, Petrology of the sedimentary rocks. Hemphill Publishing Company, Austin, $182 \mathrm{p}$.

Fuertes Prieto, M. N., Neira Campos, A., Gómez Fernández, F., Alonso Herrero, E. \& Fernández Martínez, E. 2010, Caracterización de las materias primas líticas del yacimiento Mesolítico de El Espertín (León). In: Minerales y rocas en las sociedades de la Prehistoria (Domínguez-Bella, S., Ramos Muñoz, J, Gutiérrez López, J.M. \& Pérez Rodríguez, M., Eds.), Grupo de Investigación HUM-440, Universidad de Cádiz, Cádiz: p. 169-184. (in Spanish) ("Characterization of lithic raw materials from the Mesolithic site of 'El Espertín' (León, Spain)”)

Fuertes Prieto, M. N., Neira Campos, A., Fernández Martínez, E., Gómez Fernández, F. \& Alonso Herrero, E. 2014, "Mucientes Chert" in the Northern Iberian Plateau (Spain). Journal of Lithic Studies, 1(1): 117-135. doi:10.2218/jls.v1i1.785

Fuertes-Prieto, M. N., Fernández-Martínez, E., Gómez-Fernández, F., Alonso-Herrero, E., Herrero Alonso, D., \& Neira-Campos, A. 2016, The Escalada Formation:

Characterization of a potential chert supply source in the Cantabrian Mountains (NW Spain) during prehistory. Journal of Lithic Studies, 3(2): 18 p. doi:10.2218/jls.v3i2.1421

Herrero, D. 2014, El nivel III de la cueva de La Uña (Acebedo, León): Análisis tecnológico de la industria retocada y aprovisionamiento de materias primas. $C K Q$ Estudios de Cuaternario / Kuaternario Ikasketak / Quaternary Studies, 4:15-26. (in Spanish) ("The layer III of La Uña cave (Acebedo, León): technology analysis of retouched industry and supply of raw materials")

Herrero, D. 2016, El chert paleozoico de la Cordillera Cantábrica (N de España). In: Entre ciência e cultura: Da interdisciplinaridade à transversalidade da arqueologia. Actas das VIII Jornadas de Jovens em Investigação Arqueológica (Coelho, I. P., Torres, J.B., Gil, L.S. \& Ramos, T., Eds.), Centro de História de Além-Mar - Ciências Sociais e Humanas, Universidade Nova de Lisboa and Universidade dos Açores and Instituto de Estudos Medievais - Faculdade de Ciências Sociais e Humanas, Universidade Nova de Lisboa (CHAM-CSH/UNL-UAç y IEM-FCSH/UNL), Lisbon: p. 19-25. (in Spanish) ("Paleozoic chert in the Cordillera Cantábrica (north of Spain)")

Herrero-Alonso, D., Tarriño-Vinagre, A., Neira-Campos, A., \& Fuertes-Prieto, N. 2016, Chert from the Vegamián Formation: A new raw-material supply source in the Cantabrian Mountains (NW Spain) during prehistory. Journal of Lithic Studies, 3(2): 22 p. doi: $10.2218 /$ jls.v3i2.1449

Herrero-Alonso, D. 2018: La gestión de las materias primas y cadenas operativas líticas en el Mesolítico de la vertiente sur de los Picos de Europa: La cueva de La Uña (León). PhD, University of Salamanca, Salamanca, 1078 p. (in Spanish) ("Raw material management and lithic "chaînes operatoires" in the Mesolithic of southern slope of the Picos de Europa: La Uña cave (León)”)

LithicUB 2012, LithicUB-Litoteca. Retrieved 15 November 2018. (In Spanish) (“LithicUBLithotheque") URL: http://www.lithicub.net/ 
Mangado, X., Medina, B. \& Casado, A. 2010, LithicUB: Un projet de lithothèque a l'Université de Barcelone. Les Cahiers de Géopré, (Silex et territoire préhistoriques. Avancées des recherches dans le Midi de la France) 1: electronic publication. p. 51-54. Retrieved 15 November 2018. (in French) ("Lithic_UB: A lithotheque project at the University of Barcelona")

URL: http://www.lithicub.net/public/biblio/MANGADO $\% 20 \& \% 20$ MEDINA\%20\&\%2 0CASADO_Lithic\%20UB.\%20Un\%20projet\%20de\%20lithoth\%C3\%A8que\%20\%C3 $\%$ A0\%201\%5C\%27Universit\%C3\%A9\%20de\%20Barcelone.pdf

Munsell Color, 2013, Munsell soil-color charts: with genuine Munsell color chips. Grand Rapids, Michigan, $50 \mathrm{p}$.

Neira Campos, A.; Fuertes Prieto, N.; Fernández Rodríguez, C. \& Bernaldo de Quirós, F. 2004, Le gisement mésolithique de la «cueva del Espertín», León, Espagne. In: Actes du XIV Congrès de l'UISPP, Liège, Belgique,2-8 septembre 2001. Section 7: Le Mésolithique (Crombé, P., Ed.), BAR International Series Vol. 1302, Archaeopress, Oxford: p. 129-136. (in French) ("The Mesolithic site of El Espertín cave, León, Spain")

Neira, A., Fuertes, N. \& Herrero, D. 2016, The Mesolithic with geometrics south of the 'Picos de Europa' (Northern Iberian Peninsula): The main characteristics of the lithic industry and raw material procurement. Quaternary International, 402: 90-99. doi:10.1016/j.quaint.2015.10.065

Ortega, D., Roqué, C., Terradas, X., 2016, Disponibilidad de rocas silíceas en el noreste peninsular: resultados del proyecto LITOcat. Cuadernos de Prehistoria y Arqueología de la Universidad de Granada, 26: 245-282. doi:10.30827/cpag.v26i0.7402 (in Spanish) ("Availability of siliceous rocks in the North-Eastern of Iberia: Results from the Litocat Project")

PePeEfe 2018, Pasado Presente Futuro: Iberian Peninsula geological map. WikimediaCommons. Retrieved 15 november 2018. (in Spanish) ("Past Present Future: Iberian Peninsula geological map")

URL: https://commons.wikimedia.org/wiki/User:PePeEfe\#People

Pereira, T., Farias, A., \& Paixão, E., 2016, Presenting LusoLit: A lithotheque of knappable raw materials from central and southern Portugal. Journal of Lithic Studies, 3(2): 15 p. doi:10.2218/jls.v3i2.1455

Sánchez, M., Rey, M., Rodríguez, N., Casado, A., Medina, B., \& Mangado, X. 2014, The LithicUB project: A virtual lithotheque of siliceous rocks at the University of Barcelona. Journal of Lithic Studies, 1(1): 281-292. doi:10.2218/jls.v1i1.756

Tarriño, A. 2006, El sílex en la Cuenca Vasco-Cantábrica y Pirineo Navarro.

Caracterización y su aprovechamiento en la Prehistoria. Monografías $n^{\circ} 21$, Museo Nacional y Centro de Investigación de Altamira, Madrid, 264 p. (in Spanish) ("Flint in the Vasco-Cantabrian Basin and Navarran Pyrenees. Characterisation and procurement in the Prehistory") 
Tarrino Vinagre, A., Duarte Matías, E., Santamaría Álvarez, D., Martínez Fernández, L., Fernández de la Vega, J., Suárez Ferruelo, P., Rodríguez Otero, V., Forcelledo Arena, E., Rasilla, M de la, 2013, El sílex de Pilona: caracterización de una nueva fuente de materia prima lítica en la Prehistoria de Asturias. In: Javier Fortea Pérez: Universitatis Ovetensis Magíster: Estudios en Homenaje Rasilla (de la Rasilla, M., Ed.), Universidad de Oviedo, Oviedo: p. 115-132. (in Spanish) ("Piloña flint: characterization of a new source of lithic raw material in the Prehistory of Asturias")

Tarriño, A., Elorrieta, I., García-Rojas, M., Orue, I., \& Sánchez, A., 2014, Neolithic flint mines of Treviño (Basque-Cantabrian Basin, Western Pyrenees, Spain). Journal of Lithic Studies, 1(2): 129-147. doi:10.2218/jls.v1i2.1098

Tarriño, A., Elorrieta, I. \& García Rojas, M. 2015, Flint as raw material in prehistoric times: Cantabrian Mountain and Western Pyrenees data. Quaternary International, 364: 94108. doi:10.1016/j.quaint.2014.10.061

Tarriño, A., Morgado, A., Terradas, X., 2016, Geoarqueología del sílex en la Península Ibérica: Presentación. Cuadernos de Prehistoria y Arqueología de la Universidad de Granada, 26: 7-9. (in Spanish) ("Flint geoarchaeology in the Iberian Peninsula. Presentation") doi:10.30827/cpag.v26i0.7392

Terradas, X.; Ortega, D. \& Boix, J., 2012, El projecte LITOCAT: creació d'una litoteca de referència sobre la disponibilitat de roques silícies a Catalunya. Tribuna d'Arqueologia, 2010-2011: 131-150. (in Catalan) ("The LITOCAT project: creation of a reference lithotheque on the availability of siliceous rocks in Catalonia") 